\title{
BRASIL, UNA NACIÓN EROTIZADA. LAS REPRESENTACIONES DE LA MUJER MULATA EN A REVISTA DO HOMEM (1975-1978)
}

\section{Veronica Giordano ${ }^{1}$}

\begin{abstract}
Resumen: A Revista do Homem fue la versión brasileña de la revista Playboy, publicada bajo licencia norteamericana por la Editora Abril desde agosto de 1975. A Revista do Homem apareció en el contexto de la dictadura instaurada con el golpe de Estado de 1964. Recortamos el periodo agosto 1975 - julio 1978, durante el cual el nombre Playboy estuvo prohibido en razón de la censura. De las imágenes publicadas en el período seleccionado, centraremos nuestro análisis en las aparecidas en la sección "Mulher" del número de febrero de 1976, por ser representativo de un conjunto de similares características. Se trata de un ensayo fotográfico sobre una reconocida mulata del mundo del entretenimiento nocturno: Marina Montini. Proponemos explorar cómo aparece representada en Homem la mujer mulata, qué significados aportan esas representaciones porno-eróticas en relación con la construcción del orden político y social promovido por la dictadura y cómo se ubica la revista en ese proceso.
\end{abstract}

Palabras clave: Playboy. Pornografía. Dictadura. Nación. Brasil.

INTRODUCCIÓN

A Revista do Homem fue la versión brasileña de la revista Playboy, publicada bajo licencia norteamericana por la Editora Abril desde agosto de 1975. Proponemos explorar cómo aparece representada la mujer mulata en sus páginas y qué significados aportan esas representaciones porno-eróticas en relación con la construcción del orden político y social en tiempos de dictadura. Entendemos, como sostiene Roger Chartier (1992), que las representaciones forman parte de luchas sociales por el poder y son tan importantes como las luchas económicas, y que su análisis puede develar los mecanismos por los cuales un grupo impone, o intenta imponer, una cierta concepción del mundo social.

A Revista do Homem apareció cuando la dictadura instaurada con el golpe de estado de 1964 iniciaba su fase de "distensão lenta, gradual e segura" propuesta por el gobierno del general Ernesto Geisel (1974-1979). Recortamos el período agosto 1975 julio 1978, durante el cual la Editora Abril tuvo prohibido utilizar el nombre Playboy en razón de la censura. Desde el 13 de diciembre de 1968 estaba vigente el Ato Institucional $\mathrm{N}^{\mathrm{0}} 5$ (AI-5) que había introducido la censura previa y severas medidas de "seguridad nacional". 2 Con este acta en vigencia y la aplicación de medidas que

\footnotetext{
${ }^{1}$ Doctora en Ciencias Sociales. Universidad de Buenos Aires y Consejo de Investigaciones Científicas y Técnicas (CONICET), con sede en el Instituto de Estudios de América Latina y el Caribe (IEALC), Facultad de Ciencias Sociales. CV en Grupo de Sociología Histórica de América Latina (GESHAL). Email: veronicaxgiordano@gmail.com.

2 Además del AI-5, se había dictado una nueva Constitución (1967), una nueva Ley de Prensa ( $N^{\circ} 5.250$ del 9 de febrero de 1967) y la Ley de Seguridad Nacional (No 898 del 29 de septiembre de 1969).
} 
ajustaron los mecanismos de la política a favor del poder militar, el alcance de la proclamada "distensión" fue tibio. ${ }^{3}$ Recién a mediados de 1978 la revista adoptó el emblemático nombre Playboy, y recién a fines de ese mismo año se derogó el AI-5.

Basada en la Doutrina de Segurança Nacional (DSN) con énfasis en el Desenvolvimento, la dictadura puso en marcha un proceso de modernización con industrialización. En su dimensión cultural, este proceso absorbió sin mayores inconvenientes el binomio erotismo/pornografía en la circulación y el consumo de nuevos productos culturales, como fue el caso de las revistas denominadas "masculinas". ${ }^{4}$ En tanto tal, Homem fue sin duda un producto de la cultura de masas de su época.

Siguiendo la propuesta de Peter Burke (2005), entendemos que las imágenes pueden fungir de testimonio histórico. En Homem, una revista en la cual la visualidad es un elemento vertebrador de su identidad, las imágenes son un componente valioso y todavía poco explorado para la indagación histórica. Creemos que a través del análisis de las imágenes de la mujer mulata publicadas en Homem se puede dar cuenta de los alcances del proceso modernizador de la dictadura. La mujer mulata fue símbolo de la exuberancia de la naturaleza con la que se identificó el "ser nacional" de Brasil en tiempos de dictadura, cuando DSN mediante fue utilizado para amalgamar las diferencias sociales y promocionar al país como "o país do futuro". En este artículo, no buscamos tanto analizar el binomio raza-género, aunque seguramente reflexionaremos sobre estas categorías, sino más bien mostrar cómo se construyen en las imágenes porno-eróticas de Homem los estereotipos de varón y mujer en relación con la figura de la mulata y cómo ésta ingresa discursiva e iconográficamente en el imaginario de nación de la dictadura. Entendemos que la nación, en cuanto discurso simbólico (BARBOSA, 2011), es una construcción donde se negocian las diferencias (étnicas, de género, de clase). Consideramos que la mulata es una "invención" (CORRÊA, 1996) en la que la dictadura buscó cuajar las diferencias sociales.

\section{HOMEM, PORNOGRAFÍA DOSIFICADA}

En The invention of pornography, Lynn Hunt (1993) señala las implicancias sociales y políticas del género pornografía. Sostiene que entre los años 1500 y 1800 la representación explícita de la sexualidad era una forma de criticar el orden moderno, social, político y religioso considerado legítimo. En el marco de este orden, la pornografía fue erigida como una categoría "regulatoria": a través la sexualidad como

\footnotetext{
3 En 1977 se dictó el "Pacote de Abril", un conjunto de leyes que entre otras medidas instauró la designación directa por parte del gobierno de un tercio de los senadores - los denominados senadores biónicos.

4 También en la industria cinematográfica, en el rubro películas clase $B$, surgió el género "pornochanchada", que se hizo popular en los años setenta. Se trata de comedias eróticas que no contenían escenas de sexo explícito. En buena medida, la popularidad se debió, por un lado, a la censura aplicada por el régimen a toda forma de pornografía, que obligaba a edulcorar las producciones pornográficas, y por otro lado, a las obligatorias cuotas de cine nacional que debía proyectarse en las salas, lo cual animó a muchos empresarios a incursionar en la producción cinematográfica de bajo costo de películas clase B (DENNISON, 2006, p. 136).
} 
fantasía, ésta regulaba la excitación sexual; incorporando ideas de la ciencia, la literatura, la filosofía, la política, se establecía un canon de heterosexualidad normal y normada.

Como sostiene Linda Williams (2004), en Porn studies, la industria del porno hoy puede hacer parecer a un poster de una pin-up girl como un producto habitual. Pero no hay que olvidar que la pornografía es un elemento de la cultura y por lo tanto cambiante, es decir, histórico (y tiene una historia, como bien ha mostrado Hunt). Desde esta perspectiva, hay que señalar que en los años en los que centramos nuestro análisis, 1975-1978, la genitalidad no formaba parte del repertorio de lo pornográfico en Homem pero tampoco en Playboy de Estados Unidos, de donde la revista brasileña tomaba algunos de sus contenidos.

Sin embargo, la ausencia de genitalidad no debe conducirnos a concluir que Homem no era una revista pornográfica. Ahora bien, ¿Homem se autodefinía como tal? No.

En Estados Unidos, Playboy tenía la competencia de Penthouse (desde 1969) y Hustler (desde 1974), ambas revistas más explícitas en sus figuraciones sobre el sexo y la sexualidad y socialmente reconocidas por su inscripción en el campo de la pornografía. Por ello, en los años setenta, para competir en el mercado con estos nuevos productos, Playboy actualizó su perfil y comenzó a incorporar la genitalidad como parte de su repertorio visual y discursivo. Con todo, puede acordarse (siguiendo a PITZULO, 2011, p. 8) que Playboy no se asumió como revista pornográfica y mantuvo su perfil de artefacto cultural de calidad para el consumo de masas. En Brasil, contemporáneamente, Homem siguió la misma línea de erotización de la vida cotidiana antes que la pornograficación de los cuerpos. Podemos decir que, como la Playboy de Hugh Hefner, Homem abordó la pornografía pero evitó el encasillamiento en ese rubro. En el caso de Estados Unidos, esto no fue ajeno a la radicalidad del movimiento feminista anti-porno, que adquirió mayor visibilidad hacia fines de 1970. Y en el caso de Brasil, seguramente fue un factor condicionante la censura, tanto legal como de hecho, impuesta por la dictadura.

Así, Homem se autodefinió como una revista masculina, que interesaba al hombre en un espectro amplio de temas. La nota editorial publicada en el primer número definía el perfil de lector en estos términos:

\footnotetext{
Homem exigente num país que se transforma dia a dia. Nunca, como agora, existiram maiores oportunidades para o homem conhecer-se melhor e entender o mundo que o cerca. [...] Entendendo seu mundo torna-se exigente, na medida que vê as coisas com lucidez e ideias arejadas, podendo amar e usufruir o que é bom, sofisticado e belo. [...] Revista que interessa ao homem no seu lazer, no seu prazer intelectual e também profissionalmente.
}

Y solo después de haber dicho esto, Homem refirió al objeto de ese amor y disfrute: "Tudo isso sem desprezar as boas coisas da vida: uma bela viagem, o melhor som, boas bebidas, roupa elegante, um belo jate. E, naturalmente, nas doses certas, um outro assunto de grande interesse: a mulher". El "assunto de grande interesse", que era "a mulher", estaba claro que era la mujer desnuda, o casi desnuda. Pese a ser de "grande interesse", este "assunto" aparecía, en efecto, en "doses certas". Así, los ensayos 
fotográficos de mujeres eran publicados en dos secciones: "Mulher" y "Poster", pero ellos ocupaban apenas 10 de las aproximadamente 140 páginas totales que componían cada número.

En agosto de 1975, para anunciar el primer número de Homem, la Editora Abril publicó una breve nota en el semanario Veja (otro producto de la misma casa editora). ${ }^{5}$ En la mencionada nota, Mauro Ivan Pereira de Mello, responsable de Homem y director de la revista Quatro Rodas (también producto de Abril), decía que un acuerdo con la Playboy de Hugh Hefner les permitía usar "o material [de la revista norteamericana] com a maior libertade. Ficamos com o melhor e abandonamos o que não tem interesse para o leitor brasileiro" (Veja, 13 Agosto 1975, p. 26). Abril anunciaba así la impronta nacional que tendría A Revista do Homem. En este marco, las mujeres retratadas en las páginas de la revista eran en general mujeres brasileñas, muchas veces figuras reconocidas en la escena cultural local. ${ }^{6}$

Por entonces, la norteamericana Playboy había tenido un pronunciado descenso de las ventas, en buena medida a causa de la ya mencionada aparición de las competidoras Penthouse y Hustler. Esto, sumado a la incipiente tendencia a la transnacionalización del capital, animó la "exportación" de la marca a otros países: Alemania (1972), Italia (1972), Francia (1973), México (1976) y España (1978). Así, hacia 1975, después de varios intentos frustrados de acuerdo con la Playboy de Hefner, la Editora Abril consiguió el permiso para lanzar A Revista do Homem, con materiales traducidos de la original en inglés y otros de cuño propio.

En Brasil, desde comienzos de 1970 regía el decreto-ley 1077, que siguiendo el artículo 153 de la Constitución disponía: "não serão toleradas as publicações e exteriorizações contrárias à moral e aos costumes". La norma buscaba "proteger a instituição da família". Así, el gobierno prohibió las publicaciones "obscenas", con el argumento que "tais publicações e exteriorizações estimulam a licença, insinuam o amor livre e ameaçam destruir os valores morais da sociedade Brasileira". Era un asunto de Seguridad Nacional: "o emprêgo dêsses meios de comunicação obedece a um plano subversivo, que põe em risco a segurança nacional". ${ }^{7}$ La fiscalización y la censura quedaban a cargo del Ministerio de Justicia, a través del Departamento de Policía Federal (art. 2).

\footnotetext{
5 Se trataba de una práctica frecuente de la empresa editorial: promocionar un cierto producto utilizando las páginas de sus otros productos que eran afines por el tipo de lector al que apuntaban, en este caso el varón de clase media.

${ }^{6}$ Hasta abril de 1977, cuando fue autorizada la utilización del conejito símbolo de la marca Playboy y la leyenda "Com o melhor da Playboy" en tipografía pequeña junto al nombre A Revista do Homem, todas las imágenes de tapa fueron de producción local. En todas se fotografiaban parejas porque la fotografía de una mujer sola era considerada más incitante (y por lo tanto más pornográfica) por parte de los censores. A veces el varón aparecía de modo evidente, otras veces su presencia se adivinaba por la sola presencia de una mano apoyada sobre el cuerpo de la mujer o un brazo rodeándolo. En abril de 1977 Homem no sólo retrató una mujer sola, sino que la imagen de tapa de esa mujer estaba tomada del número de febrero de 1976 de la Playboy de Estados Unidos. A partir de entonces, Abril intercaló tapas licenciadas con tapas de producción local, una estrategia que aseguraba colocar el producto en el mercado brasileño usufructuando el prestigio de la marca norteamericana.

${ }^{7}$ Decreto-ley No 1077, 26 de enero de 1970. Firmado por el presidente Emílio Garrastazu Médici (19691974).
} 
En estas circunstancias, como ya se ha dicho, Abril tuvo que desistir del nombre Playboy y adoptar el más cauto título A Revista do Homem. Optó por los disimulos en las fotografías e imágenes, una estrategia de eficiencia comercial que garantizaba tanto la continuidad de sus publicaciones como de las relaciones de sus propietarios, la familia Civita, con las altas esferas del Estado y la sociedad. Aunque no siempre del todo adecuados a los supuestos "valores morais da sociedade Brasileira", los productos de la Editora Abril fueron tolerados por el régimen en buena medida gracias a la alianza tecno-burocrático-militar con la burguesía nacional y el capital extranjero que era soporte de la dictadura (BRESSER-PEREIRA, 1978).

La Editora Abril era una empresa poderosa (y aun hoy lo es). Fue fundada hacia fines de los años cuarenta por Victor Civita. Nacido en Estados Unidos, en el seno de una familia judío-italiana, Víctor llegó a Brasil animado por su hermano César, quien en 1941 se había instalado en Argentina y fundado allí la (primera) Editora Abril. César había adquirido la representación de los derechos para América Latina de los productos de la compañía de Walt Disney y con miras de expandir los negocios, creó la firma Abril en Brasil en 1947. Pero la nueva empresa nunca operó hasta que Víctor se hizo cargo de ella en 1949 (MIRA, 2001; SCARZANELLA, 2009).

Abril de Brasil enseguida se catapultó como empresa exitosa con la publicación de $O$ Pato Donald dirigida al público infantil. Luego, en el marco de la experiencia desarrollista del gobierno de Juscelino Kubitschek (1956-1961), creció y diversificó su oferta. En los años sesenta, lanzó productos que con el tiempo se volvieron íconos de la marca: Quatro Rodas (1960), Claudia (1961), Realidade (1966), Veja (1968). Y en 1973, Nova. Este conjunto satisfacía un amplio espectro de segmentos sociales de la clase media brasileña surgida durante el impulso modernizador de los años previos, una clase media que fue interpelada como consumidora por parte del modelo de seguridad y desarrollo de la dictadura instaurada en 1964.

Así se publicó: Quatro Rodas para los varones consumidores de la industria del automóvil y del turismo de carretera; Claudia para las mujeres que cada vez más buscaban acercarse a las pautas de consumo de las mujeres modernas de Europa y Estados Unidos; Realidade y Veja para los jóvenes universitarios y sectores intelectuales en general interesados en la actualidad política; y Nova para la "nueva mujer", aquella que después de la revolución de la píldora y la minifalda ya no se identificaba tanto con el imaginario doméstico que predominantemente pregonaba Claudia.

En este marco, Homem fue una novedad editorial. Pero no era la primera publicación brasileña que incursionaba en el segmento de revistas masculinas. En noviembre de 1966 había aparecido Fairplay: a revista do homem, de la Editora Efecê de Rio de Janeiro (hasta agosto de 1971, pues fue gravemente afectada por el clima de censura y represión). Fairplay publicaba fotos de mujeres semidesnudas, pero se insertaba en el circuito de la industria cultural acompañando esas imágenes de artículos de interés general y con un diseño gráfico de calidad. En mayo de 1969, apareció la revista Ele Ela, de la empresa Bloch Editores, cuyo slogan era "uma revista para ler a dois", también con el mismo perfil de industria cultural moderna. En 1974 apareció Status, de la Editora Três, que llegó a tener una tirada de 700 mil ejemplares, compitiendo con Homem (hasta 1987, cuando aquella dejó de editarse) (MIRA, 2001; SCALZO, 2003). 
Asimismo, los temas relativos a la vida erótica y sexual de las personas no fueron privativos de las revistas que se inscribían en el segmento de revistas de hombres. También algunas revistas de actualidad dirigidas al público en general pusieron en discusión temas relativos al sexo. En enero de 1967, el № 10 de la revista Realidade presentó una edición especial titulada "A Mulher Brasileira Hoje". En la tapa, se leían frases tales como "Pesquisa: O que elas pensam e querem", "Confissões de uma moça livre", "Ciência: O corpo feminino", "Eu me orgulho de ser mãe solteira", "Por que a mulher é superior" e "Assista a um parto até o fim". El ejemplar nunca llegó al público. El 30 de diciembre de 1966, el número fue incautado por orden de la justicia, que la censuró por considerarla obscena y atentatoria contra la honra de la mujer (Veja Mulher, mayo de 2010).

El 13 de agosto de 1975, para acompañar el lanzamiento de Homem, la Editora Abril abordó el tema del sexo desde un punto de vista científico titulando en la tapa de su revista Veja: "A Ciência do Sexo". Muy probablemente, el tratamiento científico del asunto daba a las cuestiones relativas al sexo un marco de legitimidad dentro del cual Abril buscaba cobijar su flamante producto.

Con una combinación de materiales propios e importados, en su primera entrega Homem se presentó con una nota editorial firmada por el propio Victor Civita con el título: "De homem para homem", que luego devendría una sección fija de la revista. A continuación, el subtítulo presentaba una cadena de sentidos muy elocuente para el análisis de la revista en relación con el proceso de construcción del orden social y político de la dictadura. Dice: "Uma nova revista"; "Um país novo"; "Um novo homem" (A Revista do Homem, agosto de 1975, p. 5). En efecto, la revista era "nueva", pero el país también lo era. Así se fijaba u sentido de identidad entre la revista y la nación. Homem se plegaba al clima de la autodenominada "Revolução" de los militares en el poder, cuyo objetivo era crear un Brasil "nuevo". En estas circunstancias, no extraña que Homem fuera una revista bien tolerada por el régimen. ${ }^{8}$

Durante el gobierno de Emílio Garrastazu Médici (1969-1974), el “milagre econômico" dio a las clases dominantes razones suficientes para convencerse de la capacidad de potencia emergente de Brasil. El nacionalismo se exacerbó y en ese clima Editora Abril se plegó a la propaganda promovida desde el gobierno de la dictadura, que invitaba a "descubrir" Brasil. Como sostiene Maria Celeste Mira (2001, pp. 43-68), Abril hizo esto desde las páginas de Claudia y de Veja, por ejemplo. Pero, a partir de agosto de 1975, también lo hizo desde A Revista do Homem. "Descubrir" Brasil era la consigna promovida por la dictadura para "integrar" las diferencias en un todo homogéneo: la nación. En este contexto, Homem salió al mercado con licencia de Playboy pero con un claro mensaje de producto de la industria nacional (GIORDANO, 2013).

Homem se sumó al proceso de modernización cultural en curso desde los años sesenta, pero no tuvo ni el discurso didáctico-iniciático ni el discurso médico-moralista de las revistas para mujeres de la década del sesenta. La revista delimitó, para hombres

\footnotetext{
${ }^{8}$ Playboy de Brasil estuvo en la mira de los censores, pero sus editores pudieron maniobrar con astucia los obstáculos impuestos por la dictadura evitando la prohibición total de la publicación (GIORDANO, 2014).
} 
y mujeres, una cotidianeidad sexuada en la cual el sexo estaba omnipresente y su fin era la satisfacción del deseo antes que la reproducción. A diferencia de la década previa, Homem se reapropiaba y actualizaba los postulados de la liberación sexual sesentistas mostrando la desnudez con fines comerciales y de masividad.

Elizabeth Fraterrigo (2009, p. 9) sostiene que "al subrayar el nexo entre las esferas de producción y consumo, trabajo y placer, Hefner colocó el consumo privado como llave del crecimiento económico y por lo tanto del bienestar de la nación", ofreciendo "una resolución de las tensiones entre hedonismo y objetivo nacional" propias de los años de la segunda posguerra. ${ }^{9}$

En Brasil, dos décadas más tarde, Homem también asoció el estilo de vida del playboy con el bienestar de la nación, pero en ese momento los objetivos nacionales fueron los fijados por la dictadura. Durante el gobierno de Médici, la institucionalización del poder autoritario y el extraordinario crecimiento del PBI propiciaron la afirmación de una imagen de Brasil como "Brasil Grande", "Brasil Potência", el Brasil del "ame-o ou deixe-o", que siguió en vigor en los años siguientes como una de las ideas-fuerza legitimadora del orden autoritario. ${ }^{10}$ Como se ha dicho, con objetivos políticos informados por la Doutrina de Segurança Nacional e Desenvolvimento, esta imagen se edificó junto a otra que era subsidiaria, la de una Nación política y socialmente "integrada". En efecto, desde la Escola Superior de Guerra se había definido como "Objetivo Nacional" la "integración física, política, económica o social de una Nación" (NINA, 1979, p. 35). La mulata fue uno de los símbolos con los que se representó la supuesta "integración" y "grandeza" de la nación.

HOMEM, MULHER, MULATA

Las imágenes de mujeres mulatas aparecen casi exclusivamente en las secciones "Mulher" y "Poster", estando prácticamente ausentes en las caricaturas, publicidades y demás secciones de la revista. A diferencia de la sección denominada "Poster", ubicada en las páginas centrales de la revista, y en la cual en general posaban mujeres desconocidas o muy poco conocidas, en la sección "Mulher" las retratadas eran mujeres de cierto reconocimiento.

De las imágenes publicadas en el período que recortamos para nuestro análisis, por cuestiones de espacio, seleccionaremos las del número de febrero de 1976, aparecidas en la sección "Mulher" (con algunas referencias a otras secciones relacionadas). Se trata de un ensayo fotográfico de Paulo Luiz Fischberg sobre una reconocida mulata del mundo del entretenimiento nocturno: Marina Montini.

\footnotetext{
${ }^{9}$ En un sentido similar, Beatriz Preciado (2010) detecta la emergencia de un nuevo discurso sobre el sexo y la sexualidad) en el contexto de la Guerra Fría en Estados Unidos y señala especialmente la emergencia de nuevos códigos de representación de la masculinidad: Playboy pone en cuestión el orden espacial, provocando una "revolución" del espacio doméstico, que aparece colonizado por los varones a través del prototipo de playboy en bata de seda y pantuflas en su cuarto de soltero. Así, según la autora, la "pornotopía" emerge como una contranarrativa del modelo de familia nuclear, unidad de producción y consumo de las sociedades modernas.

10 Tales eran los slogans de la dictadura para significar las alternativas posibles: aceptar el poder autoritario o partir al exilio (en el mejor de los casos, pues también hubo muerte violenta y prisión política).
} 
Tanto en las imágenes como en los textos que las acompañan, Montini no escapa a los rasgos que definen el estereotipo de mujer de Playboy, es decir una mujer siempre dispuesta al sexo y con expectativas puestas fuera del tradicional espacio doméstico, es decir, una mujer presentada como una profesional que encuentra en el desempeño de su profesión (lo cual le da un signo de distinción respecto del trabajo asalariado) un ámbito de liberación (de las ataduras tradicionales). Así cuando en el texto se lee: "Minha vida pessoal fica em completo segundo plano quando trabalho. E como trabalho desde os 17 anos...", no debe entenderse un lamento sino más bien que la "bela mulata" anunciaba de ese modo su condición de soltera, apetecible para los varones de clase media urbana. Y con la frase "ainda não encontrou o amor", Marina se presentaba como "livre para amar" - tal el título con el que se abría la secuencia de fotos de la mulata en Homem (Homem, febrero de 1976, pp. 36-41). ${ }^{11}$

Uno de los textos que acompañaba a una de las fotos de Marina Montini decía: "Marina não desfaz das mulheres feministas, mais deixa bem claro: 'Eu é que não visto uma camisa dessas"“. En la foto, Marina aparece retratada sentada sobre el césped, como un animal echado, con el torso desnudo, solo un seno se adivina de perfil, el otro aparece cubierto por su largo y oscuro cabello trenzado.

En las páginas de Homem, fue frecuente la alusión al feminismo. Muy probablemente estas referencias cubrían una doble intención. Por un lado, mostrar a la revista con un discurso de actualidad, hoy diríamos "políticamente correcto", pues en 1976 el feminismo era una divisa que había adquirido notoriedad, fuera por las adhesiones que concitaba o por las críticas que provocaba. Por otro lado, y relacionado con lo anterior, Homem buscaba las maneras de no ser abiertamente ofensivo para las mujeres, quienes después de todo debían sentirse interpeladas para satisfacer al playboy que la revista promocionaba.

Mientras que otras revistas, como la irreverente $O$ Pasquim, comprometieron "seu propósito libertário, ao assumir uma postura misógina, voltando sua mordacidade, igualmente, para as mulheres que se decidiram pela luta com vistas a atingir direitos e/ou que no seu cotidiano assumiam atitudes consideradas como inadequadas à feminilidade e às relações estabelecidas entre os gêneros" (SOIHET, 2005, p. 594), Homem fue condescendiente con la lucha de las mujeres por sus derechos. Era una cuestión de supervivencia, si la revista quería instalar la idea de un varón del tipo playboy, necesitaba cuestionar las relaciones establecidas entre los géneros. En esto el discurso de Homem se acoplaba al de las feministas (quienes, por su lado, no dejaron de atacar la marca Playboy y las revistas masculinas en general por ser promotoras de la mercantilización del cuerpo femenino).

No obstante, hay que aclarar que Homem fue condescendiente con el feminismo en "doses certas", pues como queda demostrado en el texto citado arriba ("“Eu é que não visto uma camisa dessas" "), obviamente la incitación al consumo de la (semi)desnudez femenina estaba siempre antes que cualquier atisbo de promoción de las ideas feministas.

\footnotetext{
${ }^{11}$ Las fotos del ensayo en cuestión pueden verse en http://garotadaplayboy.blogspot.com.ar/2012/01/playboy-revista-homem-1976marina.html?zx=135c40d5411d5f0a. Consultado por última vez el 19 de septiembre de 2014.
} 
Hasta aquí la figuración de la mulata como objeto sexual no difiere tanto de la figuración de la mujer del playboy como objeto sexual. El punto es que Marina Montini es mulata y tal como anuncia el título del ensayo fotográfico que la presenta como "livre para amar", ella "volta à natureza".

En las fotos se observa la intención de fundir el cuerpo de la mulata con la naturaleza. En una de ellas, Marina aparece de espaldas, sus nalgas se adivinan desnudas con el simple sostén de una tanga, de la cual solo se ven los hilos que rodean sus voluptuosas caderas. Su dorso aparece surcado por una trenza negra, larga y cubierta de margaritas, como si las flores estuvieran orgánicamente integradas a su cabellera. El fondo es verde, intenso. Marina aparece semidesnuda, simple, sobre el césped, con un horizonte sin marcas. En esta foto, es claro que la mulata es representada como una mujer-animal, que corporiza una sexualidad salvaje.

En los años sesenta y setenta, esta "imagen" de la mulata/naturaleza se erigió como absolutamente positiva, suspendiendo los calificativos que asociaban a la mulata a la amoralidad y el desorden. La identidad mulata/naturaleza condensa sentidos muy abigarrados en las representaciones sociales de Brasil. Estos sentidos tuvieron en Emiliano Di Cavalcanti a uno de sus más conspicuos promotores. Di Cavalcanti fue uno de los creadores de la Semana de Arte Moderna (São Paulo, 1922), que reivindicó lo propiamente brasileño contra el positivismo europeizante. En 1927, realizó el cuadro "Mulatas", uno de los tantos que caracterizaría su estilo irreverente, en el cual predominaban las mujeres mulatas y el clima de fiesta. En la obra de Di Cavalcanti, las mulatas aparecían en escenas en las cuales resaltaba la sensualidad femenina, reforzada por el recurso a colores fuertes y cuerpos delineados por trazos simples. En los años veinte, esta "imagen" convivía con discursos que descalificaban al sujeto social mulata, por conllevar amoralidad y desorden. Pero con el tiempo, en los años sesenta y setenta, la "imagen" de la mulata fue despojada de cualquier sentido negativo y se consagró como uno de los elementos iconográficos del proyecto de modernización de la dictadura.

El desarrollo económico, resultante de las políticas de industrialización y subsidios de la década previa al golpe de 1964, había dado origen a una nueva clase obrera cuya conciencia de clase fue contrapesada por el denominado discurso nordestino e ideología de la "baianidade", instrumento de dominación simbólica de las clases dominantes para diluir los conflictos sociales (OLIVEIRA, 1987). Después del golpe, la "baianidade" se convirtió en un proyecto comercial que estuvo fuertemente promovido a través de la naciente industria del turismo. Bahia era presentada como la tierra de la felicidad. Enseguida, esta identidad se proyectó a la nación toda, e incluso también al ámbito internacional. No es casual que en 1966 se hubiera creado EMBRATUR y luego en 1968 se hubiera creado BAHIATURSA, órgano estadual dedicado al desarrollo turístico de la región. Estas empresas divulgaban la imagen de un Brasil equiparado a "um paraíso de mulatas" y donde el carnaval era el ámbito para toda licencia sexual.

Como en la obra de Di Cavalcanti, donde la mulata siempre aparece fundida con la naturaleza y connotando los placeres de la carne, en otra de las fotos del ensayo que retrata a Marina Montini en Homem, la mulata aparece como un individuo del reino 
animal, desnuda ${ }^{12}$, apoyada sobre sus cuatro extremidades sobre el césped, con la mirada desafiante. En la misma línea que la imagen comentada más arriba, en esta Montini aparece como una mujer hipersexualizada e hipererotizada. Esta representación cercana al mundo animal y la naturaleza salvaje aparece matizada en los textos que acompañan a las fotos. En ellos, Marina Montini es presentada como "estrela" de la noche y como "musa de Di Cavalcanti".

Por aquel entonces tenía 26 años. Pero, tal como Homem coloca en la voz de la modelo, ella había comenzado su carrera a los 17. En 1965 recibió el título "Mulata Quarto Centenário" de Rio de Janeiro, en un certamen que fue parte de los festejos por la conmemoración de la fundación de la ciudad. En 1967 comenzó a posar como modelo del célebre pintor Emiliano Di Cavalcanti (1897-1976), que la había visto retratada en un póster de promoción de la revista Quatro Rodas y la contactó para que posase para él. En los primeros años setenta, también trabajó en varias películas marginales (aunque nunca con un papel protagónico), entre ellas "Um uísque antes, um cigarro depois", una comedia erótica del cine clase B. Y fue parte del elenco que regenteara el empresario Ricardo Amaral en el exclusivo Golden Room del hotel Copacabana Palace. En 1972, también participó del elenco de Brazil Export, una producción del famoso showman de la noche carioca Abelardo Figueiredo, montada en el célebre Canecão de Rio de Janeiro.

En los textos, la mulata hablaba en primera persona, ya no era hablada por otros. Además, Marina no era una mulata anónima, sino una mulata con renombre, profesional, cuyo oficio se inscribía en una de las industrias más pujantes de la modernización cultural de la dictadura: el show business de la noche carioca y paulista.

No es posible afirmar con certeza si los testimonios de las modelos retratadas en Homem eran efectivamente testimonios propios, o si por el contrario la revista ponía en boca de ellas los mensajes que la línea editorial buscaba transmitir. Muy posiblemente esto último haya sido la tónica. El testimonio de Lívia Mund permite avanzar en esta segunda hipótesis. Lívia había posado para la sección "Poster" del primer número de Homem a los 19 años, después de lo cual consiguió afirmar su carrera de modelo en Brasil y en Europa (Alemania, Italia, Suiza), volviendo a posar en Homem en el número de marzo de 1978, esta vez ya en la sección "Mulher". Entrevistada en 2012 por la revista Quem, ante la pregunta de si aceptaría posar en las revistas de ahora con la estética que estas tienen hoy (no tan "bem comportadas" como en los años setenta), Lívia responde: "Aceitaria se pudesse fazer uma reunião prévia com a produção e o fotógrafo e participar da seleção, o que naquela época não era possível". ${ }^{13}$ De este testimonio puede deducirse que la voz de las modelos no era muy tenida en cuenta en aquellos años, con lo cual es probable que los textos que acompañaban a las fotos fueran parte de la puesta en escena sugerida por el staff editorial.

\footnotetext{
12 A diferencia de las pinturas de Di Cavalcanti, en Homem la foto de la mulata (y cualquier mujer retratada desnuda) disimulaba las partes íntimas. Es que por la censura, en general obsesionada con las fotos más que con los textos de Homem, sólo se podía mostrar un seno de costado, nunca el desnudo podía ser frontal (y lo mismo sucedía con las nalgas). Así, Marina aparece cubriendo con sus brazos, cuál patas de una pantera, sus dos senos. 13

Quem Acontece (Rio de Janeiro), Agosto 2012. En http://revistaquem.globo.com/QUEMNews/noticia/2012/08/aos-56-anos-1-capa-da-playboy-livia-mund-e-voluntaria-em-centro-jovem.html. Visitado en agosto de 2014.
} 
Se tratase realmente de la voz de la modelo o fuese ésta parte de una estrategia editorial, es importante poner de relieve las imágenes textuales que matizan la construcción visual de la mulata for export: en los textos hay indicios de una mulata de carne y hueso, mucho más una mulata persona que una mulata "imagen". Con todo, los matices son muy débiles y la mulata que predomina es la mulata-imagen, que según Mariza Corrêa (1996, p. 48), en los años sesenta y setenta se convirtió en un género "de ser" ("algo assim como o equivalente a um gênero literário"). La autora adjudica un rol importante a Jorge Amado, Emiliano Di Cavalcanti y Oswaldo Sargentelli en esta "invención" del género mulata. ${ }^{14}$

¡A tal punto la mujer mulata era una mujer "imaginaria" que hasta podía no ser mulata! En el número de Homem de agosto de 1976, en la sección "Pontos de vista", donde se publicaban las cartas de los lectores, se publica una página de fotos bajo el título "A nudez de Sônia-flor", en referencia a la película que había llevado la historia de Jorge Amado Dona Flor e seus dois maridos a la pantalla grande (Homem, agosto de 1976, pp. 8-9). La protagonista era Sônia Braga.

En la carta, el lector celebraba una nota publicada en el número de febrero, el mismo en el cual aparecía retratada Marina Montini, cuyo tópico era "O sexo no cinema nacional". El lector decía estar informado acerca de la aparición de un "novo ciclo de cinema baiano" y consultaba a Homem sobre la veracidad de un rumor: ¿se estaba rodando "Gabriela" (por Gabriela, cravo e canela, también de Jorge Amado) con "a deliciosa Sônia Braga toda nua"?

La novela Gabriela... había sido llevada a la TV en el muy popular formato de telenovela en 1975, con la misma actriz de protagonista. Como sostiene Corrêa (1996, p. 48), para reforzar la idea de mulata "imaginária", "a imagem de Gabriela é, muito provavelmente, mais aquela projetada pela Rede Globo do que a imagem textual do romance que leva seu nome".

En la fase populista-desarrollista (1945-1964) inmediatamente anterior a la instauración de la dictadura, el novelista Jorge Amado había sido uno de los grandes y fundamentales mentores de la exaltación de la cultura de Bahia. En 1945 publicó Bahia de todos os santos, el texto que quizás mejor condensa la idea de una identidad baiana fuertemente vinculada a la idea de pueblo, y específicamente a la idea de pueblo trabajador. Pero en una segunda fase de sus novelas, Amado incursionó más profundamente en las relaciones sexo-raciales. Así, en 1958, publicó la novela Gabriela, cravo e canela. Históricamente situada en Ilhéus, el relato muestra aspectos de la vida social vinculada al auge de la exportación de cacao de las primeras décadas del siglo XX y los negocios de los "coronéis do cacau" que se mezclaban con la diversión sexual en el "cabaré Bataclan". La novela ofrece una visión positiva de la mezcla racial representada en la figura de la mulata, sin olvidar por ello la violencia de género, étnica y de clase.

\footnotetext{
14 Sargentelli fue un famoso un presentador/conductor vinculado a la radio desde fines de los años cuarenta, y luego a la televisión. Por la osadía de las preguntas que proponía a sus entrevistados en los programas, estos fueron prohibidos durante la dictadura. Hacia fines de los años sesenta volvió al ruedo con un show que se presentaba en casas nocturnas, el "show de mulatas". Este producto se presentó en varios clubes de Río de Janeiro - el Oba-Oba, su casa sede desde 1973, quizás la más célebre. Así, Sargentelli fue creador de un nuevo rubro de entretenimiento, contribuyendo a consolidar en el imaginario nacional la figura de la mulata como símbolo de la brasilianidad.
} 
En el contexto de la dictadura, esa mezcla racial y el mito de la baianidade pasaron a ser concebidos como amalgama de las diferencias para el "objetivo" de integración nacional "con seguridad y desarrollo". Esto se aprecia bien en la telenovela Gabriela rodada en 1975, en la cual Sônia Braga representó el papel de mulata, ipero ni ella misma, y ni siquiera el público, la consideraban mulata! Denise Camargo (2006) describe una escena en la que claramente se observa esto:

\begin{abstract}
Sônia Braga recém-saída de Nova York é entrevistada por Regina Casé para o programa Brasil Legal da Rede Globo, na década de 90. E a pergunta vem: 'como as pessoas se identificavam com você, mulata brasileira'? E a resposta vem: 'ninguém me via como mulata, aliás, eu era reconhecida nas ruas pelo meu trabalho, eu era uma branca comum lá'. E a entrevistadora segue: 'mas é claro que há negros na sua família'. Sônia se defende: 'eu sei que tem índios, mas negros eu não conheço, será que tem'? E a Casé não deixa por menos: 'nossa, com esse cabelo, esse nariz, claro que tem. Eu também tenho, olha a minha cara. Meus ascendentes negros eu sei quem são. Tem até fotografia deles lá em casa, negrões mesmo'.
\end{abstract}

Del mismo modo, Stephanie Dennison afirma que Sônia Braga es percibida en Brasil en todo caso como "morena" antes que como "mulata". Para sustentar esta afirmación, la autora cita a Angela Gilliam quien sostiene que alguien que en Estados Unidos lucharía para pasar por blanco, en Brasil no pasaría por negro. Según la autora, Sônia Braga es un claro ejemplo del proceso de blanqueamiento de las identidades raciales en Brasil. Incluso, Dennison (2006, p. 137) provee otras fuentes donde la popular actriz refiere a sus ancestros como de origen europeo e indígena, siendo nulas las referencias a cualquier origen negro.

En respuesta a la citada carta del lector, Homem contestó que todavía no había noticias de Gabriela en formato cinematográfico, pero que ya estaba estrenándose Dona Flor e seus dois maridos, protagonizado por la misma actriz. Y a modo de promoción, Homem adelantaba algunas fotos de Sônia semidesnuda, por eso el título "A nudez de Sônia-flor". ${ }^{15}$

Como parece haber ocurrido con las declaraciones de las modelos, también es muy probable que las cartas de lectores hayan sido en realidad un recurso de Homem para afirmar una determinada línea editorial o para reforzar tal o cual contenido. Cierta o no, la carta nos sirve para subrayar la construcción de la mulata como "imagen", incluso corporizada en mujeres que como Sônia Braga eran consideradas "brancas" (o en todo caso "morena", pero nunca "mulata" o "negra"). La mulata era entonces un objeto de consumo de la sociedad de masas: en los shows nocturnos, en la televisión, en el cine, en las revistas.

En los años sesenta y setenta, con el desarrollo industrial y la concomitante modernización cultural, la mulata bahiana de los años veinte y treinta, estigmatizada por su "cor", fue reemplazada por la mulata carioca, un "género" (exitoso) en sí mismo, un ícono de la sociedad de consumo del Brasil "Grande", del Brasil for export.

De hecho, en el mismo número de agosto de 1976 en el que apareció la carta del lector interrogando sobre Sônia Braga, en la sección "Mulher", y bajo el título "As

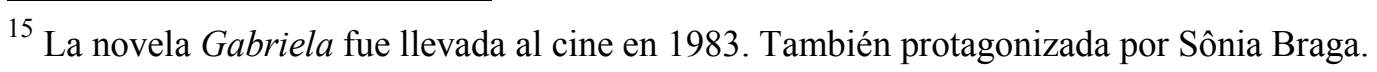


mulatas do Sargentelli”, apareció otro ensayo fotográfico que abonaba la idea del Brasil "paraíso de mulatas". Allí, el estereotipo de mujer mulata era definido por Sargentelli con referencias a Samba da minha terra, una canción con la cual suele identificarse a la nación brasileña.

Pero Sargentelli le cambió la letra:

\begin{abstract}
Eu amo uma boa mulata de cintura fina, coxinha grossa, carinha de safada, boa dentadura e cheirosa, que anda, fala, dorme, ri e chora, senta, levanta, mexe, remexe, deixando a moçada com água na boca. E quem não gosta de mulata, bom sujeito não é, é ruim da cabeça ou então é viado mesmo" (testimonio de Sargentelli en GOMES, 2009, p. 83). ${ }^{16}$
\end{abstract}

Como sostiene Corrêa (1996, p. 43), "a hierarquia sexual não estava em discussão". Pero en el testimonio de Sargentelli observamos una jerarquización interna, que se añade a la jerarquización básica: mujer / varón. Dentro del tipo masculino, el varón puede ser heterosexual o "viado". La mulata cuya imagen fue promovida tanto desde el mundo del espectáculo como desde la industria del turismo, era un objeto de consumo para el varón moderno heterosexual, blanco, letrado, propietario, etc.

En el imaginario nacional, en el cual la mulata es figura central, hay jerarquizaciones. Y Homem las reproduce sin demasiados cuestionamientos. El tipo de mujer que se "empareja" (en el sentido de formar pareja) con el varón imaginado por Homem es una mujer blanca. En este imaginario social, la mulata sigue siendo un objeto de consumo. La mulata queda suspendida de toda jerarquización. Tal como afirma la misma Corrêa, la mulata es un género "de ser", con las características particulares (que Sargentelli resume muy claramente), no es ni blanca ni negra. Y aunque tiene voz propia, no tiene identidad: es una mulata iconográfica, imaginaria, inventada. Ella es uno de los íconos que componen la heterosexualidad del varón de Homem, consumidor de las fantasías sexuales que la mulata vehiculiza.

En razón de todas estas jerarquías, mientras la mulata-imagen era la representación hipererotizada de la nación del Brasil "Grande", la mulata real, de carne y hueso, Marina Montini, quedó socialmente postergada. Montini tuvo una carrera internacional. Fue reconocida en Paris y en Roma. Pero murió en 2006, a los 58 años, enferma del hígado por el consumo excesivo del alcohol, en una casa de retiro para artistas de Rio de Janeiro, sin dinero y sin fama.

PALABRAS FINALES

Homem abordó la pornografía sin ser una revista meramente pornográfica, priorizando en este abordaje la difusión de la cultura nacional. El análisis de las imágenes de la mujer mulata en Homem permite observar los alcances del proceso modernizador de la dictadura. La mujer mulata, con su naturaleza exuberante, fue una imagen construida como representación de la nación brasileña. La mulata-imagen fue un

\footnotetext{
${ }^{16}$ La letra original de la canción dice: "Quem não gosta de $s a m b a$, bom sujeito não é. É ruim da cabeça ou doente do pé". El subrayado es mío.
} 
recurso discursivo e iconográfico de la dictadura para ocultar las diferencias sociales tras el velo de la democracia racial y así promocionar al país como "o país do futuro".

Era una representación erotizada de la nación -en rigor, puede decirse, era una representación hipererotizada. Es precisamente el exceso de erotismo el que hace de la mujer mulata una "invención", dejando a la mujer real postergada.

Homem construyó estereotipos fijos de varón y de mujer. El lector masculino era un tipo muy particular: varón heterosexual, blanco, urbano, moderno, de clase media / alta, sin estado civil explicitado o preferencial (casado o soltero, da igual). La revista encumbraba el placer, el cuidado del cuerpo, el gusto refinado en los consumos (autos, bebidas, viajes, música, y "mujeres bellas") como signos distintivos de ese varón moderno. A este tipo masculino le correspondía un tipo femenino también muy particular. La mujer ideal para el playboy era una mujer libre, que privilegiaba el placer sobre la conyugalidad (y los valores que ésta traía consigo: seguridad económica, estabilidad emocional en el seno de una familia bien constituida, etc.). Se trata de una nueva figura cultural: la mujer soltera que, en contraste con la solterona, poseía todos atributos positivos: era independiente, no tenía ataduras sociales, era capaz de autoabastecerse y estaba dispuesta al placer sexual.

La (semi)desnudez del cuerpo femenino era ofrecida como objeto de placer a los ojos del varón consumidor. Y aunque en razón de lo señalado en el párrafo de arriba, también puede hacerse una lectura positiva del rol de la mujer en Homem, ella no alcanza a la mujer mulata.

En Homem, la mujer ideal del playboy irrumpe en la dicotomía varón activo/mujer pasiva para mostrarse como sujeto activo de la vida social. Las mujeres que Homem encumbraba eran siempre mujeres profesionales, con una vida propia aunque claro está que siempre estaban disponibles para el varón que quisiera tomarlas-. En relación con estos dos tipos, masculino y femenino, la mulata era un género "de ser". A diferencia de la mujer blanca idealizada por el playboy como la compañera perfecta, la mulata seguía siendo un objeto de consumo. Aunque tenía nombre y voz propios, como Marina Montini, cuya voz aparece en varias oportunidades entrecomillada en la nota que acompaña al ensayo fotográfico, la mulata no tenía identidad propia: era la mulata "imaginaria" para una identidad nacional (hiper)erotizada.

En este sentido, Homem fue una revista que no confrontó con el régimen. Fue un emprendimiento comercial que se benefició de la alianza tecno-burocrática y militar con las burguesías nacionales que la dictadura propició. Si en relación con otros tópicos tuvo impulsos críticos, estos no alcanzaron la dimensión racial y étnica. Bien por el contrario, Homem contribuyó a reforzar la idea de "democracia racial" promovida por la dictadura.

REFERENCIAS

BRESSER-PEREIRA, Luiz Carlos. O Colapso de uma aliança de classes. São Paulo: Editora Brasiliense, 1978.

BURKE, Peter. Visto no visto. El uso de la imagen como documento histórico. Barcelona: Crítica, 2005.

CAMARGO, Denise. Identidade negra e mestiçagem no Brasil: uma reflexão sobre o processo da fotografia das heranças compartilhadas. In VI Encontro dos Núcleos de Pesquisa - XXIX Congresso Brasileiro de Ciências da Comunicação - Intercom, 2006. 
CHARTIER, Roger. El mundo como representación. Historia Cultural: entre práctica y representación. Barcelona: Gedisa, 1992.

CORRÊA, Mariza. Sobre a invenção da mulata. In Cadernos Pagu. n. 6, v. 7, 1996, pp. 33-50.

DENNISON, Stephanie. The new brazilian bombshell: Sônia Braga, race and cinema in the 1970s, in DENNISON, Stephanie and LIM, Song Hwee (eds). Remapping world cinema: identity, culture and politics on film. London and New York: Wallflower Press, 2006.

FAGUNDES BARBOSA, Márcia. Nação, um discurso simbólico da modernidade. In Crítica Cultural. Palhoça, Santa Catarina, v.. 6, n. 1, pp. 203-216, jan/jul, 2011. Disponible en http://www.portaldeperiodicos.unisul.br/index.php/Critica_Cultural/article/view/734/pdf_19

FRATERRIGO, Elizabeth. Playboy and the making of the good life in modern America. New York: Oxford University Press, 2009.

GIORDANO, Verónica. Entre el deseo y la censura. El sexo en imágenes en la revista Playboy de Brasil (1975-1978), ponencia presentada en las Jornadas Interdisciplinarias de Estudios de Género y Estudios Visuales, Mar del Plata, 22 y 23 de abril de 2014. Disponible en https://docs.google.com/file/d/0B9dOA6MzswDyV0pud3ZSRmlQekE/edit

Revolución, sexo y política en Brasil en los años setenta. Un análisis desde las notas sobre comida de la revista Homem (Playboy). In Cordis: Revista Eletrônica de História Social da Cidade, São Paulo (Brasil), n. 10, enero-junio, 2013.

GOMES, Mariana Selister. La construcción del Brasil como un paraíso de mulatas: del imaginario colonial al marketing turístico. In Sociedad Hoy, n. 17, 2009, pp. 75-87. Disponible en:

$<$ http://www.redalyc.org/articulo.oa?id=90219257007>

HUNT, Lynn. The invention of pornography, 1500-1800: obscenity and the origins of modernity. New York: Zone Books, 1993.

MIRA, Maria Celeste. O Leitor e a banca de revistas: a segmentação da cultura no século XX. São Paulo: Olho d'Agua; FAPESP, 2001.

NINA, Andrés. La doctrina de seguridad nacional y la integración latinoamericana. In Nueva Sociedad, No 27, 1979, p. 33-50.

OLIVEIRA, Francisco de. O Elo perdido: classe e identidade de classe. São Paulo: Brasiliense, 1987. PRECIADO, Beatriz. Pornotopía. Arquitectura y sexualidad en "Playboy" durante la Guerra Fría. Barcelona: Anagrama, 2010.

SCALZO, Marília. Jornalismo de revista. São Paulo: Contexto, 2003.

SCARZANELLA, Eugenia. Entre dos exilios: Cesare Civita, un editor italiano en Buenos Aires, desde la guerra mundial hasta la dictadura militar (1941-1976). In Revista de Indias, $n$. 245, 2009, pp. 65-94.

WILLIAMS, Linda. Porn Studies. Proliferating pornographies on scene. An introduction. In WILLIAMS, Linda (org.). Porn studies. Durham and London: Duke University Press, 2004, pp. 1-23.

Recebido em 19/09/2014. Aprovado em 24/11/2014.

Title: Brazil, an eroticized nation. The representations of the mulatto woman in A Revista do Homem (1975-1978)

Abstract: A Revista do Homem was the Brazilian version of Playboy magazine. It has been published under the American license by Editora Abril since August 1975. A Revista do Homem was issued in the context of the dictatorship established after the 1964 coup. We cut the period August 1975 - July 1978, during which Editora Abril did not use the name Playboy because of censorship. The analysis is focused on the section "Mulher" of the issue of February 1976, as it is representative of a selection of images of similar characteristics. The section shows a photo essay of a recognized mulatto woman who was very well-known in the Carioca nightlife: Marina Montini. We aim at exploring how Homem represented the mulatto woman, what meanings these porn-erotic representations brought up in relation to the construction of the social and political order promoted by the authoritarian regime and what the role of Homem was in that process.

Keywords: Playboy. Pornography. Dictatorship. Nation. Brazil. 
